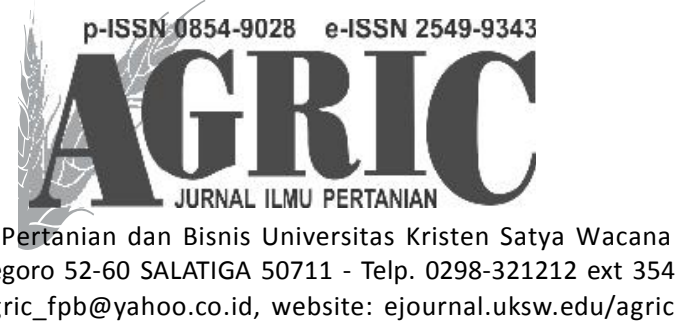

\title{
ANALISIS USAHA KERAJINAN BAMBU SKALA RUMAH TANGGA DI KELURAHAN MALUMBI KECAMATAN KAMBERA KABUPATEN SUMBA TIMUR
}

\section{ANALYSIS ON HOUSEHOLD BAMBOO HANDICRAFT BUSINESS IN THE MALUMBI VILLAGE KAMBERA SUB-DISTRICT, EAST SUMBA DISTRICT}

\author{
Nikodemus Samuel Taru, Nanik Dara Senjawati, dan Vini Arumsari \\ Program Studi Agribisnis \\ Fakultas Pertanian Universitas Pembangunan Nasional "Veteran" Yogyakarta \\ Jalan SWK 104 (Lingkar Utara), Condong Catur, Yogyakarta 55283 \\ email:nicho_taru@yahoo.co.id
}

Diterima 3 Juli 2017, disetujui 14 Juli 2017

\begin{abstract}
This study aimed to analyze the advantages, Break Even Point on bamboo handicraft business in the Village Household Scale Malumbi, District Kambera, East Sumba district. The research method using census method, takes the form of primary and secondary data for January to February 2016. Data collection technique were interview, observation, documentation, recording, and literature. The method of analysis using the analysis of the advantages and Break Even Point. Results from the study showed that bamboo handicraft business industry household scale in 2015 in the village of Malumbi make a profit of Rp.489.745.393,00, and reached a point Break Even Point for bamboo handicrafts 0.930 units, 6,918 units and woven bamboo craft craft chicken confinement 6.017 unit.
\end{abstract}

Keywords: Bamboo, Profit, Break Even Point 


\begin{abstract}
ABSTRAK
Penelitian ini bertujuan untuk menganalisis keuntungan, Break Even Point pada usaha kerajinan bambu Skala Rumah Tangga di Kelurahan Malumbi, Kecamatan Kambera, Kabupaten Sumba Timur. Metode penelitian menggunakan metode sensus, diperlukan berupa data primer dan sekunder selama bulan Januari sampai Desember 2015. Teknik pengumpulan data adalah wawancara, observasi, dokumentasi, pencatatan dan studi pustaka. Metode analisis menggunakan analisis keuntungan dan Break Even Point. Hasil dari penelitian menunjukan bahwa industri usaha kerajinan bambu skala rumah tangga pada tahun 2015 di Kelurahan Malumbi, Kecamatan Kambera, Kabupaten Sumba Timur memperoleh keuntungan sebesar Rp.489.745.393,00, dan mencapai titik Break Even Point untuk kerajinan bambu kursi dan meja 1 unit, kerajinan gedek 9 unit dan kerajinan kurungan ayam 6 unit.
\end{abstract}

Kata Kunci: Bambu, Keuntungan, Break Even Point

\section{PENDAHULUAN}

Bambu merupakan sumberdaya alam yang dapat diperbaharui serta memiliki keunggulan dari segi sosial, ekonomi dan budaya, diantaranya cepat tumbuh hingga menjadi sumber penghasilan masyarakat pedesaan, dapat mengurangi polusi udara, air serta mengendalikan adanya erosi dan tanah longsor, sehingga tanaman bambu sangat tepat digunakan untuk rehabilitasi lahan kritis, konservasi tanah miring dan rawan longsor serta dapat dipakai untuk memperbaiki estetika lingkungan di perkotaan. Tanaman bambu yang banyak terdapat di wilayah Indonesia bukanlah sekedar tanaman, apabila mampu dibudidayakan dan diberdayakan dapat dihasilkan batang bambu dengan kualitas yang baik sehingga mampu memberikan nilai tambah yang besar karena bambu dapat dijadikan bahan bangunan maupun kerajinan tangan.

Kerajinan bambu merupakan salah satu karya seni asli Indonesia yang telah dikembangkan secara turun menurun sebagai sumber penghasilan dan kehidupan rakyat, tidak banyak orang yang mengetahui bahwa bambu mampu memberikan nilai tambah yang lebih besar apabila digarap secara maksimal. Pemahaman seperti itu untuk mengubah persepsi masyarakat dari pemanfaatan bambu secara tradisional menjadi suatu komoditi yang lebih berdaya guna dengan menerapkan teknologi dan sentuhan seni, sehingga bambu dapt menjadi komoditi yang mampu mendatangkan keuntungan bagi pengrajin (Daniel 2002).

Perkembangan di Daerah Nusa Tenggara Timur khususnya di Kabupaten Sumba Timur, diarahkan pada perkembangan pertanian yang mencakup pertanian itu sendiri dan di luar pertanian misalnya transportasi, jasa, perdagangan dan industri. Perluasan pembangunan di sektor non pertanian membuka kesempatan berkembangnya industri kecil dan industri rumah tangga serta memberikan kesempatan berusaha yang lebih besar pada pengusaha kecil golongan ekonomi lemah untuk memperluas usahanya serta dapat menciptakan pemerataan kerja dan berusaha bagi segenap lapisan masyarakat.

Barang-barang hasil industri memerlukan dukungan daya beli masyarakat. Umumnya pembeli barang-barang hasil industri sebagian besar berada dalam lingkungan sektor pertanian. Untuk memenuhi kebutuhan hidup dan juga memenuhi kebutuhan peralatan dan bahan untuk usaha di sektor pertanian barang hasil industri, masyarakat ini harus ditingkatkan lebih dulu pendapatannya yang dilakukan melalui kegiatan intensifikasi, ekstensifikasi, diversifikasi, ataupun 
rehabilitasi. Pengembangan industri juga harus mempertimbangkan keberadaan masyarakat dan sektor pertaniannya sendiri yang suatu saat juga berfungsi sebagai pemasok bahan baku. Sistem usaha agribisnis yang berdaya saing, dapat dicirikan antara lain oleh efisiensi yang tinggi, mampu merespon perubahan pasar secara cepat dan efisien, menghasilkan produk bernilai tambah tinggi, menggunakan inovasi teknologi sebagai sumber pertumbuhan produktivitas dan nilai tambah (Daniel, 2002). Dalam arti luas ada kaitannya antara sektor industri dan pertanian khususnya industri yang mengolah hasil pertanian dan meningkatkan nilai tambah merupakan prakondisi proses pembangunan negara yang sedang tumbuh dan berkembang. Kaitan ini hanya akan terjalin dengan baik jika sektor industri muncul sebagai akibat dari kuatnya sektor pertaniannya. Dengan demikian, ketergantungan antara sektor pertanian dan sektorindustri adalah ketergantungan yang saling menguntungkan. Salah satu keterikatan itu adalah agroindustri yang sebagian besar menghasilkan produksi yang meningkatkan kemampuan produksi dan daya beli sektor pertanian.

Usaha Mikro, kecil dan menengah (UMKM) merupakan salah satu kekuatan pendorong terdepan dalam pembangunan ekonomi. Gerak sektor UMKM sangat penting untuk menciptakan pertumbuhan dan lapangan pekerjaan. UMKM cukup fleksibel dan dapat dengan mudah beradaptasi dengan pasang surut dan arah permintaan pasar. UMKM dapat menciptakan lapangan pekerjaan lebih cepat dibandingkan sektor usaha yang lainnya, dan juga cukup terdiversifikasi serta memberikan kontribusi penting dalam ekspor dan perdagangan. Karena itu UMKM merupakan aspek penting dalam pembangunan ekonomi yang kompetitif. Pembangunan industri kecil dikaitkan dengan pembangunan perdesaan dan pola pertambahan penduduk di pedesaan, maka sektor industri kecil mempunyai peranan yang cukup besar, baik dilihat dari model ekonomi maupun dari model teknis yang digunakan relatif murah dan mudah, sehingga dapat meningkatkan pendapatan petani dan dapat memperluas lapangan pekerjaan dan dapat meningkatkan pendapatan golongan ekonomi lemah. Hal tersebut dihubungkan dengan jumlah penduduk dengan jumlah penduduk yang ada di pedesaan yang sebagian besar merupakan penduduk dengan tingkat pendidikan yang tergolong rendah dan ekonomi lemah serta pola hidupnya tergantung pada sektor pertanian baik besar maupun kecil.

Pengembangan industri kecil yang sudah banyak di lingkungan masyarakat diharapkam juga akan dapat meningkatkan nilai tambah dari hasil pertanian. Hasilnya dapat dipasarkan di dalam negeri maupun di ekspor. Pengembangan industri kerajinan yang merupakan bagian dari agroindustri dapat dilakukan melalui pemanfaatan hasil pertanian secara optimal, disamping itu pengembangan agroindustri diharapkan dapat menambah penyerapan tenaga kerja, selain itu hasil yang diperoleh dapat meningkatkan kesejahteraan masyarakat di desa tersebut, mengingat kebutuhan hidup terus menerus mengalami peningkatan.

Faktor yang ikut memberikan adil besar dalam seluruh tahapan dari pengembangan sektor pertanian dan sub sektor agroindustri adalah ketersediaan sumber daya manusia yang sesuai baik kualitas maupun jumlahnya, selain itu ketersediaan sumber daya alam yang tersedia pada daerah tersebut dapat dimanfaatkan sebagai bahan baku untuk mendukung seluruh rangkaian proses agroindustri tersedia.

Di Kelurahan Malumbi, KecamatanKambera, Kabupaten Sumba Timur terdapat industri kerajinan yang menjadikan bambu sebagai 
bahan utama dalam menjadikan sebuah kerajinan. Di Kelurahan Malumbi telah berkembang usaha kerajinan bambu mempunyai tujuan memanfaatkan sumber daya alam yang tersedia di Kabupaten Sumba Timur dan mengolahnya menjadi suatu produk seperti kursi bambu yang memiliki nilai tinggi sehingga dapat membuka lapangan pekerjaan bagi penduduk di sekitarnya sehingga dapat memperoleh pendapatan yang lebih tinggi baik tenaga kerja maupun usaha tersebut.

Usaha kerajinan bambu di Kelurahan Malumbi, Kecamatan Kambera, Kabupaten Sumba Timur dijalankan dalam skala industri kecil atau industri rumah tangga dan telah berkembang cukup lama.Produksi unggulan industri kerajinan bambu di Kelurahan Malumbi yaitu gedek, tempat tidur, kursi dan meja, kurungan ayam.Perkembangan usaha kecil dan menengah (UKM) tidak mendapat perhatian yang serius dari berbagai kalangan baik pemerintah ataupun maryarakat umum, tidak adanya sarana dan prasarana serta fasilitas yang diberikan oleh pemerintah, sehingga pengrajin bambu menggunakan dana sendiri untuk membangun usaha kerajinan bambu.

Kegiatan usaha yang terdapat di Kelurahan Malumbi, Kecamatan Kambera salah satunya adalah industri usaha kerajinan bambu skala rumah tangga yang dimiliki oleh hampir sebagian masyarakat Kelurahan Malumbi. Usaha tersebut berdiri sejak tahun 1985an yang pertama dirintis oleh bapak Hunga Remi Andung sekeluarga. Usaha kerajinan bambu di Kelurahan Malumbi menggunakan bahan baku bambu dari Desa Kiri Tana dan Marada Mundi.

Kerajinan bambu jenis kursi dan meja, gedek dan kurungan ayam merupakan salah satu usaha yang paling banyak diusahakan oleh pengrajin, kerena kerajinan tersebut yang banyak diminati dan dikonsumsi oleh masyarakat Sumba Timur pada umumnya untuk digunakan sebagai dinding rumah dan perabot rumah tangga dengan harga yang murah. Kerajinan bambu di Sumba Timur tersebar dalam 2 Kecamatan yaitu Kecamatan Kambera dan Wairinding, usaha mereka sudah berkembang dari 1980an.

Pemasaran industri kerajinan bambu ini hanya sebatas pulau Sumba dan pengrajin menjual atau memasarkan kerajinan mereka keluar Sumba seperti Alor, Sabu, Flores, Kupang apabila ada konsumen yang memesan kerajinan tersebut. Tetapi yang memproduksi kerajinan bambu dalam skala yang besar yaitu pada kecamatan Kambera, sehingga penulis melakukan penelitian di Kecamatan tersebut.

Dalam penelitian ini juga peneliti menggunakan break even point (titik impas) untuk mengetahui titik impas atau pulang pokok dari hasil penjualan industri kerajinan bambu oleh pengrajin. Ini dilakukan supaya peneliti mengetahui berapa besar keuntungan serta pulang pokok karena pengrajin tidak memperoleh laba ataupun kerugian dari hasil penjualan produk kerajinan bambu (Munawir, 2012). Masalah yang ingin diteliti meliputi (1) Apakah usaha kerajinan bambu skala rumah tangga di Kelurahan Malumbi, Kecamatan Kambera, Kabupaten Sumba Timur menguntungkan?, (2) Apakah usaha kerajinan bambu skala rumah tangga di Kelurahan Malumbi, Kecamatan Kambera, Kabupaten Sumba Timur mencapai Break Even Point (BEP) atau titik impas?

Berdasarkan latar belakang tersebut, penelitian ini bertujuan menganalisis keuntungan usaha kerajinan bambu skala rumah tangga di Kelurahan Malumbi, Kecamatan Kambera, Kabupaten Sumba Timur, dan menganalisis Break Even Point atau impas usaha kerajinan bambu skala rumah tangga di Kelurahan Malumbi, Kecamatan Kambera, Kabupaten Sumba Timur. 


\section{METODE KAJIAN}

Penelitian ini adalah studi kasus karena Kelurahan Malumbi merupakan sentra industri kerajinan bambu yang ada diKecamatan Kambera dibandingkan 8 Kelurahan lainnya yang ada di Kecamatan Kambera, Kabupaten Sumba Timur. Kelurahan Malumbi, merupakan satu-satu kelurahan yang ada di Kecamatan Kambera, Kabupaten Sumba Timur yang mendapatkan pinjaman modal usaha 120 juta dari pemerintah daerah melalui program anggur merah. Metode penelitian yang digunakan adalah deskriptif analitis, yaitu dengan menggali informasi sebanyak mungkin dari masyarakat, suatu metode dalam meneliti sekelompok manusia, suatu obyek, suatu set kondisi, suatu sistem pemikiran ataupun suatu set peristiwa saat sekarang. Tujuannya membuat gambaran deskripsi, gambaran atau lukisan secara sistematis, faktual, dan akurat, mengenai faktafakta, sifat-sifat serta hubungan antar fenomena yang diselidiki (Nazir,2011).

Teknik analisis menggunakan analisis keuntungan usaha per bulan selama tahun 2015, analisis profitabilitas, dan analisis titik impas, meliputi titik impas produk dan titik impas harga. Unit analisis adalah seluruh pengrajin bambu di Kelurahan Malumbi sejumlah 30 pengrajin bambu. Keuntungan adalah selisih positif antara penerimaan total dengan biaya total (Sudarman, 2002). Break Even point memberikan petunjuk bahwa tingkat produksi telah menghasilkan pendapatan yang sama besarnya dengan biaya produksi yang dikeluarkan artinya usaha kerajinan bambu tidak untung dan tidak rugi.

\section{HASIL DAN PEMBAHASAN}

Kelurahan Malumbi termasuk dalam wilayah Kecamatan Kambera Kabupaten Sumba Timur, terletak sekitar $5 \mathrm{~km}$ dari pusat pemerintahan Kecamatan Kambera, 12 km dari ibu kabupaten SumbaTimur. Sarana dan lembaga perekonomian yang ada di Kelurahan Malumbi sudah lengkap dengan adanya koperasi sebagai sarana simpan pinjam dan terdapatnya toko-toko yang dapat menunjang kelancaran dan kemajuan perekonomian untuk membangun kelurahan usaha kerajinan bambu skala rumah tangga.

Penjualan hasil usahakerajinan harus memberikan pembagian keuntungan yang layak bagi pengrajin. Cakupan, daerah pemasaran dapat memanfaatkan fasilitas dan sarana pemerintah, misalnya melalui promosi yang dapat dilakukan secara perorangan ataupun secara bersamasama dengan bantuan pemerintah. Untuk mengelola dan mengem-bangkan industri ini maka pengrajin terus menerus menggali untuk menciptakan ide-ide dalam membuat kerajinan kursi, gedek, tempat tidur, lemari, meja, dan juga tirai dari bambu yang sesuai dengan keinginan konsumen. Selain itu pengusaha juga memberikan penanganan secara langsung dalam proses pembuatan kerajinan sehingga produk yang dihasilkan mempunyai daya saing di pasaran.

Kerajinan bambu untuk meningkatkan keuntungan pengrajin harus memproduksi dan meningkatkan output. Untuk menghasilkan produk pengrajin perlu adanya tenaga kerja untuk melakukan proses produksinya, sehingga dengan adanya industri ini dapat memberikan kesempatan kerja kepada masyarakat sekitar dan dapat mengurangi pengangguran yang ada di Kelurahan Malumbi. Untuk meningkatkan keuntungan pengrajin harus dapat melihat dan memperhatikan jumlah input yang dikeluarkan dan jumlah output yang dihasilkan. Apabila jumlah input yang dikeluarkan lebih besar dari pada jumlah output yang dihasilkan maka pengrajin tersebut mengalami kerugian tetapi apabilajumlah input yang dikeluarkan lebih kecil dari jumlah output yang dihasilkan maka pengrajin tersebut mengalami keuntungan. 
Industri kerajinan bambu yang merupakan bagian dari industri diharapkan mempunyai kemampuan untuk meningkatkan pertumbuhan ekonomi, selain itu juga untuk memenuhi kebutuhan konsumen masyarakat maupun penyerapanhasil produksi pertanian yang mengolah sumber-sumber lokal, sehingga diharapkan dapat meningkatkan sumber penghasilan dan kesejahteraan bagi petani. Volume produksi usaha kerajinan bambu di Kelurahan Malumbi selama bulan Januari 2015Desember 2015 untuk menentukan volume produksi pada berbagai variasi produk saat $\mathrm{BEP}$, mngetahui besarnya keuntungan dari usaha kerajinan bambu skala rumah tangga.

\section{Biaya Total}

Biaya total adalah penjumlahan antara biaya tetap dan biaya variabel. Biaya total ini diperhitungkan untuk mengetahui berapa besarnya seluruh biaya yang dikeluarkan oleh pengrajin bambu setiap bulannya. Adapun untuk mengetahui besarnya biaya total yang dikeluarkan oleh pengrajin bambu selama tahun 2015 dapat dilihat pada Tabel 1.

Berdasarkan Tabel 1 dapat diketahui bahwa biaya total yang dikeluarkan oleh pengrajin usaha bambu skala rumah tangga terendah pada bulan September sebesar Rp 33.794.387,00. Sedangkan biaya total tertinggi pada bulan Mei Rp 46.424.233,00. karena pada bulan tersebut pesanan kursi mengalami kenaikan sehingga mempengaruhi biaya variabel. Persentase dari biaya variabel lebih besar dibandingkan biaya tetap adalah sebesar 98,92\%.

Biaya merupakan nilai korbanan yang dikeluarkan dalam serangkaian proses produksi. Biaya dalam penelitian ini merupakan keseluruhan biaya yang dikeluarkan untuk proses pembuatan kerajinan bambu baik biaya yang benar-benar dikeluarkan maupun biaya yang tidak benar-benar dikeluarkan. Biaya yang dikeluarkan oleh para pengrajin bambu

Tabel 1 Biaya Total Pengrajin Usaha Kerajinan Bambu Skala Rumah Tangga di Kelurahan Malumbi, Kecamatan Kambera Tahun 2015

\begin{tabular}{lrrr}
\hline \multicolumn{1}{c}{ Bulan } & $\begin{array}{c}\text { Biaya Tetap } \\
(\mathrm{Rp})\end{array}$ & $\begin{array}{c}\text { Biaya Variabel } \\
(\mathrm{Rp})\end{array}$ & \multicolumn{1}{c}{$\begin{array}{c}\text { Jumlah } \\
(\mathrm{Rp})\end{array}$} \\
\hline Januari & $407.833,33$ & 40.955 .000 & 41.362 .833 \\
Februari & $407.833,33$ & 40.553 .720 & 40.961 .553 \\
Maret & $440.333,33$ & 41.375 .000 & 41.815 .333 \\
April & $404.833,33$ & 40.567 .680 & 40.972 .513 \\
Mei & $409.833,33$ & 46.014 .400 & 46.424 .233 \\
Juni & $409.833,33$ & 42.531 .240 & 42.941 .073 \\
Juli & $396.500,00$ & 40.689 .600 & 41.086 .100 \\
Agustus & $429.000,00$ & 34.134 .000 & 34.563 .000 \\
September & $443.666,66$ & 33.350 .720 & 33.794 .387 \\
Oktober & $460.333,33$ & 34.611 .000 & 35.071 .333 \\
Nopember & $429.833,33$ & 35.411 .680 & 35.841 .513 \\
Desember & $462.333,33$ & 38.633 .400 & 39.095 .733 \\
\hline Total & $5.102 .166,67$ & 468.827 .440 & 473.929 .607 \\
Rata-Rata & $425.180,55$ & 39.068 .953 & 39.494 .134 \\
Persentase & $1,07 \%$ & $98,92 \%$ & $100 \%$ \\
\hline
\end{tabular}

Sumber: Analisis Data Primer Tahun 2015 
di Kelurahan Malumbi terdiri dari biaya tetap dan biaya variabel. Biaya tetap adalah biaya yang digunakan dalam proses pembuatan kerajinan bambu yang besarnya tidak dipengaruhi oleh jumlah produk yang dihasilkan. Biaya tetap dalam usaha ini meliputi biaya penyusutan alat. Biaya penyusutan alat sebenarnya tidak benar-benar dikeluarkan oleh pengusaha kerajinan bambu, tetapi karena dalam penelitian ini menggunakan konsep keuntungan, maka biaya ini harus diperhitungkan.Biaya penyusutan alat memberikan kontribusi terbesar dalam perhitungan biaya tetap yang dikeluarkan pengrajin bambu. Peralatan yang digunakan dalam pelaksanaan proses produksi pembuatan kerajinan bambu masih tergolong sederhana dan dibeli pada awal mereka mulai menjalankan usaha kerajinan bambu atau dengan kata lain penggantian terhadap alat baru relatif sangat lama sehingga biaya penyusutan peralatan tidak terlalu besar. Biaya rata-rata penyusutan alat pada usaha kerajinan bambu di Kelurahan Malumbi selama satu bulanya itu sebesar Rp. 407.833,00. Usaha kerajinan bambu biaya tetap yang paling banyak dikeluarkan selama tahun 2015 adalah biaya tenaga kerja sebesar Rp.8.298.500,00. Karena dalam memproduksi usaha kerajinan bambu ini sangat dibutuhkan tenaga kerja yang cukup banyak sehingga biaya yang dikeluarkan untuk membayar tenaga kerja sangat tinggi.

Pada usaha kerajinan bambu biaya yang paling banyak dikeluarkan selama tahun 2015 adalah biaya variabel sebesar Rp. 468.827.440,00. Komponen paling banyak yang dikeluarkan tiap bulannya adalah biaya bahan baku dan bahan penolong. Hal ini terjadi karena adanya kenaikan harga bahan baku dan penggunaan biaya tergantung jumlah produksi kerajinan bambu, semakin banyak kerajinan yang di produksi maka semakin tinggi biaya variabel yang dikeluarkan. Biaya bahan baku dan bahan penolong yang harus dikeluarkan tiap bulannya adalah sebesar Rp. 468.827.440,00. Agar dapat menekan biaya variabel yang sangat tinggi maka pengrajin harus mencari bahan baku yang murah dan berkualitas, menggunakan bahan penolong yang umur ekonomisnya lebih lama serta mencari sumber bahan baku yang lebih dekat dengan tempat produksi sehingga dapat mengurangi biaya transportasi.

\section{Analisis Penerimaan}

Penerimaan adalah perkalian total produk dengan harga persatuan produk, sehingga dalam usaha kerajinan bambu di Kelurahan Malumbi, Kecamatan Kambera, penerimaannya adalah total dari hasil penjualan, yaitu total produk yang terjual dengan harga jual produk.

Total penerimaan usaha kerajinan bambu di Kelurahan Malumbi, Kecamatan Kambera. Penerimaan dengan menjumlahkan total produksi dengan harga jual usaha kerajinan bamb. Adapun untuk mengetahui besarnya penerimaan usaha kerajinan bambu di Kelurahan Malumbi, Kecamatan Kambera selama tahun 2015 dapat dilihat pada Tabel 2.

Berdasarkan pada Tabel 2 dapat diketahui bahwa penerimaan terendah usaha kerajinan bambu yang diperoleh pada bulan Januari sebesar Rp. 76.775.000,00. Sedangkan penerimaan tertinggi diperoleh usaha kerajinan di Kelurahan Malumbi pada bulan desember sebesar Rp. 86.600.000,00. Pada bulan Desember penerimaan kerajinan bambu mengalami kenaikan yang sangat pesat dikerenakan pada bulan tersebut kebutuhan konsumen akan kurungan ayam sangat meningkat dikarenakan akhir tahun banyak masyarakat yang membutuhkan kerajinan bambu. Persentase penerimaan usaha kerajinan bambu gedek lebih besar dibandingkan dengan penerimaan usaha kerajinan kursi dan meja, dan kurungan ayam sebesar 33,19\%. 
Tabel 2 Penerimaan Total Pengrajin Usaha Kerajinan Bambu di Kelurahan Malumbi, Kecamatan Kambera Tahun 2015

\begin{tabular}{lrrrr}
\hline \multicolumn{1}{c}{ Bulan } & $\begin{array}{c}\text { Kursi dan Meja } \\
(\mathrm{Rp})\end{array}$ & $\begin{array}{c}\text { Gedek } \\
(\mathrm{Rp})\end{array}$ & $\begin{array}{c}\text { Kurungan ayam } \\
(\mathrm{Rp})\end{array}$ & $\begin{array}{c}\text { Penerimaan } \\
(\mathrm{Rp})\end{array}$ \\
\hline Januari & 28.000 .000 & 26.775 .000 & 22.000 .000 & 76.775 .000 \\
Februari & 27.200 .000 & 26.850 .000 & 22.200 .000 & 77.850 .000 \\
Maret & 24.000 .000 & 26.175 .000 & 22.500 .000 & 78.275 .000 \\
April & 20.800 .000 & 27.000 .000 & 22.300 .000 & 78.900 .000 \\
Mei & 22.400 .000 & 26.625 .000 & 29.000 .000 & 86.025 .000 \\
Juni & 19.200 .000 & 26.850 .000 & 22.400 .000 & 79.650 .000 \\
Juli & 24.800 .000 & 26.175 .000 & 22.800 .000 & 77.775 .000 \\
Agustus & 24.000 .000 & 26.175 .000 & 24.000 .000 & 79.775 .000 \\
September & 23.200 .000 & 26.625 .000 & 23.900 .000 & 80.125 .000 \\
Oktober & 28.800 .000 & 26.775 .000 & 24.300 .000 & 81.475 .000 \\
Nopember & 23.200 .000 & 26.850 .000 & 23.200 .000 & 80.450 .000 \\
Desember & 29.600 .000 & 27.000 .000 & 29.200 .000 & 86.600 .000 \\
\hline Total & 295.200 .000 & 319.875 .000 & 287.800 .000 & 963.675 .000 \\
Rata-Rata & 24.600 .000 & 26.656 .250 & 23.983 .333 & 80.306 .250 \\
Persentase & $30,63 \%$ & $33,19 \%$ & $29,84 \%$ & $100 \%$ \\
\hline Sumber: Analisis Data Primer Tahun 2015 & & &
\end{tabular}

Penerimaan total yang diperoleh dari usaha kerajinan bambu skala rumah tangga merupakan selisih antara total biaya yang dikeluarkan dengan harga jual produk kerajinan. Rata-rata penerimaan yang diperoleh usaha kerajinan bambu adalah sebesar Rp. 80.306.250,00 per bulan dengan memproduksi 2116,66 unit kerajinan yang terdiri dari kerajinan kursi meja, gedek dan kurungan ayam. Penerimaan yang diperoleh pengrajin kerajinan bambu dipengaruhi oleh perbedaan jumlah produk yang dijual dengan biaya total yang dikeluarkan. Berdasarkan penerimaan total yang diperoleh, maka dapat diketahui persentase penerimaan untuk kerajinan bambu kurungan ayam adalah sebesar $30,63 \%$, gedek $33,19 \%$ dan kurungan ayam $29,84 \%$.

Persentase penerimaan untuk kerajinan bambu jenis gedek sangat tinggi karena yang paling banyak diproduksi tiap bulannya adalah gedek. Ini dikarenakan kebutuhan konsumen untuk kerajinan gedek tiap bulannya meningkat. Agar dapat memenuhi kebutuhan konsumen yang selalu meningkat maka pengrajin harus meningkatkan produksi kerajinan bambu.

\section{Analisis Keuntungan}

Keuntungan merupakan tujuan yang hendak dicapai dalam suatu usaha. Keuntungan pada usaha kerajinan bambu di Kelurahan Malumbi diperoleh dari selisih antara penerimaan dengan biaya total. Adapun untuk mengetahui besarnya keuntungan pengusaha usaha kerajinan bambu di Kelurahan Malumbi, Kecamatan Kambera dapat dilihat dari Tabel 3.

Berdasarkan Tabel 3 dapat diketahui bahwa keuntungan total terendah yang diperoleh usaha kerajinan bambu di Kelurahan Malumbi, Kecamatan Kambera diperoleh pada bulan Januari sebesar Rp. 35.412.167. Sedangkan penerimaan tertinggi diperoleh usaha kerajinan bambu skala Rumah tangga di Kelurahan Malumbi pada bulan Desember sebesar Rp. 47.504.267 dikarenakan bulan tersebut 
Tabel 3 Keuntungan Total PengrajinUsaha Kerajinan bambu skala Rumah Tangga di Kelurahan Malumbi, Kecamatan Kambera pada tahun 2015

\begin{tabular}{lccc}
\hline \multicolumn{1}{c}{ Bulan } & $\begin{array}{c}\text { Penerimaan } \\
(\mathrm{Rp})\end{array}$ & $\begin{array}{c}\text { Biaya Total } \\
(\mathrm{Rp})\end{array}$ & $\begin{array}{c}\text { Keuntungan } \\
(\mathrm{Rp})\end{array}$ \\
\hline Januari & 76.775 .000 & 41.362 .833 & 35.412 .167 \\
Februari & 77.850 .000 & 40.961 .553 & 36.888 .447 \\
Maret & 78.275 .000 & 41.815 .333 & 36.459 .667 \\
April & 78.900 .000 & 40.972 .513 & 37.927 .487 \\
Mei & 86.025 .000 & 46.424 .233 & 39.600 .767 \\
Juni & 79.650 .000 & 42.941 .073 & 36.708 .927 \\
Juli & 77.775 .000 & 41.086 .100 & 36.688 .900 \\
Agustus & 79.775 .000 & 34.563 .000 & 45.212 .000 \\
September & 80.125 .000 & 33.794 .387 & 46.330 .613 \\
Oktober & 81.475 .000 & 35.071 .333 & 46.403 .667 \\
November & 80.450 .000 & 35.841 .513 & 44.608 .487 \\
Desember & 86.600 .000 & 39.095 .733 & 47.504 .267 \\
\hline Total & 963.675 .000 & 473.929 .607 & 489.745 .393 \\
Rata-rata & 80.306 .250 & 39.494 .134 & 40.812 .116 \\
\hline
\end{tabular}

Sumber: Analisis Data Primer Tahun 2015

merupakan akhir tahun dan menyambut kedatangan tahun baru sehingga banyaknya permintaan kerajinan bambu seperti kursi dan meja serta gedek.

Keuntungan yang diperoleh dari usaha kerajinan bambu merupakan selisih antara penerimaan dengan total biaya. Keuntungan rata-rata yang diperoleh oleh pengrajinan yaitu R p. 40.812.116,00 per bulan dengan memproduksi 393 kerajinan bambu per bulan. Keuntungan yang diterima oleh pengrajin bambu dipengaruhi oleh perbedaan jumlah produk yang dijual dan biaya yang dikeluarkan. Berdasarkan keuntungan yang diperoleh, maka dapat diketahui profitabilitas atau tingkat keuntungan dari usaha kerajinan bambu skala rumah. Dalam hal ini total penerimaan yang diperoleh sebesar Rp. 963.675.000,00, yaitu hasil dari penjualan kursi dan meja, gedek dan kurungan ayam, sedangkan biaya total yang dikeluarkan sebesar Rp. 217.012.500,00. Profitabilitas atau tingkat keuntungan dari usaha kerajinan bambu skala rumah tangga di
Kelurahan Malumbi rata-rata perbulan sebesar $1,033 \%$. Artinya sebesar 1,033 dalam penggunaan Rp. 1,00 akan menghasilkan keuntungan sebesar Rp. 1,033.

Perhitungan keuntungan saja tidak cukup, sehingga perlu dicari besarnya BEP atau titik impas. BEP mempunyai tujuan untuk mengetahui besarnya BEP per satuan produk agar pengrajin dapat mengetahui titik pulang pokok pada suatu usaha kerajinan bambu skala rumah tangga. Diketahui rata-rata pada saat BEP volume produksi Kursi dan meja sebesar 0,930 unit dan penerimaan sebesar Rp. 744.406,84. Sedangkan untuk volume produksi kerajinan bambu gedek adalah sebesar 37,08 unit dan penerimaannya sebesar Rp. 29.666.667,00. Dan rata-rata pada saat BEP untuk volume poduksi gedek sebesar 8,98 unit dan penerimaannya sebesar Rp. 668.868,41. Sedangkan untuk volume produksi kerajinan gedek adalah sebesar 355,41 unit dan penerimaannya sebesar Rp. 26.656.250,00. Serta rata-rata pada saat $\mathrm{BEP}$ volume produksi kerajinan bambu 
kurungan ayam sebesar 6,017 unit dan penerimaan sebesar Rp.601.798,62. Sedangkan untuk volume produksi kurungan ayam adalah sebesar 239,83 unit dan penerimaannya sebesar Rp. 23.983.333,00. Penerimaan usaha kerajinan bambu gedek sangat meningkatkan dikarenakan produksi kerajinan yang paling diminati serta memenuhi kebutuhan konsumen adalah kerajinan gedek yang dapat dijadikan sebagai dinding rumah.

\section{Profitabilitas}

Profitabilitas merupakan hasil bagi antara keuntungan dengan total biaya yang dinyatakan dalam persen. Adapun untuk mengetahui besarnya rata-rata profitabilitas dari usaha kerajinan bambu di Kelurahan Malumbi dapat dilihat pada Tabel 4 .

Tabel 4 Profitabilitas Pengrajin Usaha kerajinan bambu Skala Rumah Tangga di di Kelurahan Malumbi, Kecamatan Kambera Tahun 2015

\begin{tabular}{llll}
\hline No & \multicolumn{1}{c}{ Uraian } & \multicolumn{1}{c}{ Jumlah } \\
\hline 1. & Total Keuntungan & Rp. & 489.745 .393 \\
2. & Total Biaya (TC) & Rp. & 473.929 .607 \\
3. & Profitabilitas & & $1,033 \%$ \\
\hline
\end{tabular}

Menunjukkan bahwa profitabilitas atau tingkat keuntungan dari usaha kerajinan bambu pada bulan Januari hingga Desember adalah sebesar $1,033 \%$. Usaha kerajinan bambu skala rumah tangga termasuk dalam kriteria menguntungkan karena memiliki nilai profitabilitas lebih dari nol.

\section{Break Even Point (Titik Pulang Pokok)}

Untuk mengetahui jenis kerajinan ini menggunakan istilah sales mix dan product mix. Untuk memudahkan dalam penulisan produk kerajinan bambu, maka kerajinan kursi dan meja diberi simbol 1, gedek simbol 2, dan kurungan ayam simbol 3. Analisis break even point total atas dasar penjualan dalam rupiah sebagai berikut:

$$
\begin{aligned}
\mathrm{BEP}(\text { dalam satuan rupiah }) & =\frac{F C}{1-\frac{V C}{S}} \\
& =\frac{15.306 .500}{1-\frac{354.327 .440}{963.675 .000}} \\
& =24.180 .884,67
\end{aligned}
$$

Jadi, BEP total atas dasar penjualan dalam rupiah adalah Rp. 24.180.884,67.

Sales Mix $1: 2: 3=29.666 .667: 26.656 .250$ :

$$
23.983 .333
$$

BEPTotal $=$ Rp. $24 \cdot 180 \cdot 884,64$

Break Even Point masing-masing produk menggunakan:

$\mathrm{BEP}($ dalam rupiah $)=\frac{S i}{\sum_{i=1}^{3} S i} \times Q \mathrm{BEP}($ Total $)$

Keterangan:

$\mathrm{Si}$ : Nilai Penjualan

S1: Nilai Penjualan produk 1

S2: Nilai Penjualan Produk 2

S3: Nilai penjualan produk 3

$$
\begin{aligned}
\operatorname{BEP} 1 & =\frac{29.666 .667}{963.675 .000} \times 24.180 .884,67 \\
& =744.406,84
\end{aligned}
$$

Jadi BEP atas dasar penjualan dalam rupiah untuk produk kerajinan bambu kursi dan meja adalah sebesar Rp. 744,406,84

$$
\begin{aligned}
\mathrm{BEP} 2 & =\frac{26.656 .250}{963.675 .000} \times 24.180 .884,67 \\
& =668.868,41
\end{aligned}
$$

Jadi BEP atas dasar penjualan dalam rupiah untuk produk kerajinan bambu gedek adalah sebesar Rp. 668.868,41

$$
\begin{aligned}
\text { BEP } 3 & =\frac{23.983 .333}{963.675 .000} \times 24.180 .884,67 \\
& =601.798,62
\end{aligned}
$$

Jadi BEP atas dasar penjualan dalam rupiah untuk produk kerajinan bambu kurungan ayam adalah sebesar Rp. 601.798,62 
$\mathrm{BEP}($ per unit $)=\frac{B E P i}{P i}$

Keterangan :

BEPi: Break even point masing-masing kerajinan bambu

$P i$ : Harga Jual masing-masing kerajinan bambu

Produk Mix 1:2: $3=445: 4265: 1698$

Harga jual $1: 2: 3=800.000: 75.000: 100.000$

$\begin{aligned} \mathrm{BEP} 1 & =\frac{744.406,84}{800.000} \\ & =1 \\ \mathrm{BEP} 2 & =\frac{668.868,41}{75.000} \\ & =9\end{aligned}$

$\mathrm{BEP} 3=\frac{601.798,62}{100.000}=6$

Jadi BEP atas dasar kuantitas produk yang dijual untuk produk usaha kerajinan bambu Kursi dan meja, gedek, kurungan ayam untuk semua jenis kerajinan sebesar 1 unit, 9 unit, 6.

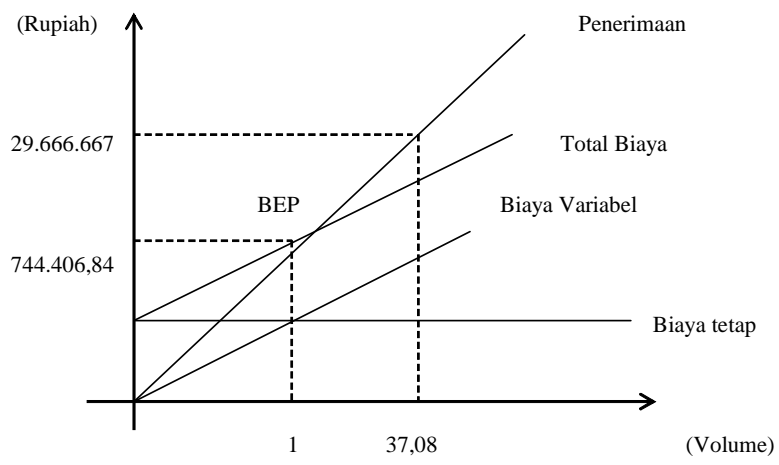

Gambar 1 Kurva BEP Usaha Kerajinan Bambu Kursi dan Meja

Berdasarkan Gambar 1 dapat diketahui bahwa usaha kerajinan bambu kursi dan meja di Kelurahan Malumbi, Kecamatan Kambera mencapai BEP dalam rupiah sebesar Rp.744.406,84 dengan BEP unit sebesar 1 unit. Sehingga agar tidak memperoleh kerugian pengrajin harus memproduksi kerajinan bambu kursi dan meja sebesar 1 unit.

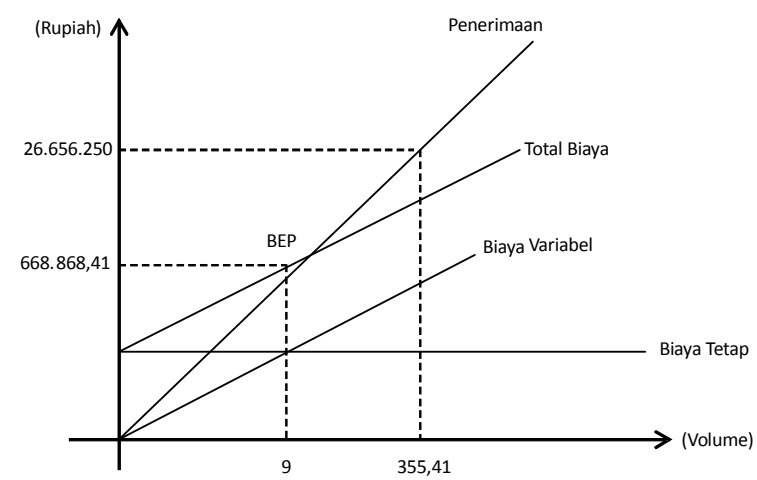

Gambar 2 Kurva BEP Usaha Kerajinan Bambu Gedek

Berdasarkan Gambar 2 dapat diketahui bahwa usaha kerajinan bambu gedek di Kelurahan Malumbi, Kecamatan Kambera mencapai BEP dalam rupiah sebesar Rp. 668.868,41 dengan BEP unit sebesar 9 unit. Sehingga agar tidak memperoleh kerugian ataupun keuntungan pengrajin harus memproduksi kerajinan bambu gedek sebesar 9 unit.

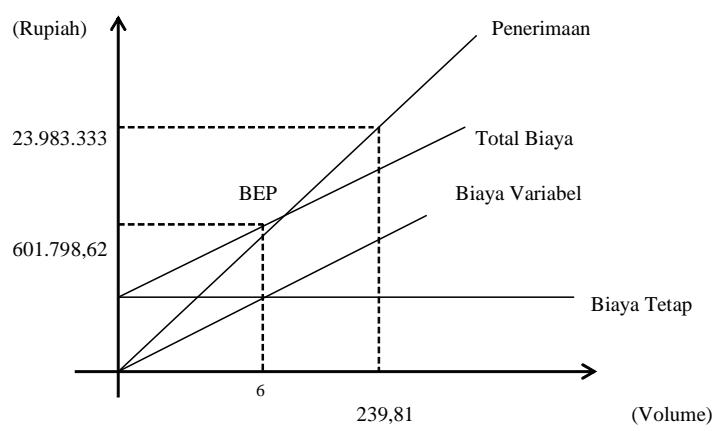

Gambar 3 Kurva BEP Usaha Kerajinan Bambu Kurungan Ayam

Berdasarkan Gambar 3 dapat diketahui bahwa usaha kerajinan kurungan ayam di Kelurahan Malumbi, Kecamatan Kambera mencapai BEP dalam rupiah sebesar Rp.601.798.62 dengan BEP unit sebesar 6 unit. Sehingga agar tidak memperoleh " zrugian maupun keuntungan pengrajin harus memproduksi kerajinan bambu kurungan ayam 6 unit.

Dari ketiga kurva di atas dapat diketahui bahwa volume produksi usaha kerajinan bambu pada berbagai variasi produk kerajinan bambu telah mencapai BEP dengan rata-rata volume 
produksi tertinggi terdapat pada kerajinan bambu gedek sebesar 355,41 unit dengan nilai Rp 26.656.250 dan titik impasnya sebesar 8,98 unit dengan nilai $\operatorname{Rp} 668.868,41$.

Berdasarkan hasil analisis data diperoleh data volume produksi kerajinan bambu kursi dan meja sebesar 0,930 unit dan volume produksi kursi dan meja pada saat BEP adalah sebesar 37,08 unit, hal ini menunjukkan bahwa volume produksi kerajinan bambu kursi dan meja mencapai BEP.

BEP setiap jenis produk mengalami perbedaan, hal ini tersebut disebabkan oleh volume penjualan yang berbeda-beda sehingga menyebabkan nilai penjualan dalam rupiah juga berbeda-beda. Perbedaan volume penjualan disebabkan minat konsumen yang berbedabeda terhadap kebutuhan kerajinan bambu. Untuk meningkatkan dan mempertahankan volume produksi dan volume penjualan, harus menggunakan input secara efisien, sehingga penerimaan meningkat, biaya total dapat ditekan dan keuntungan usaha kerajinan bambu akan meningkat.

Penggunaan saluran distribusi oleh pengrajin bambu skala rumah tangga mempunyai banyak keuntungan, diantaranya membantu pengembangan produk (terutama untuk daerah pemasaran yang jauh), membantu mengembangkan pasar, dan membantu memberi masukan dalam perbaikan-perbaikan produk kerajinan bambu.

Penguatan produk kerajinan bambu agar bertahan lama dilakukan dengan meningkatkan kualitas kerajinan kursi meja, gedek dan kurungan ayam yang lebih baik yaitu dengan melakukan finishing dan variasi kerajinan bambu yang diminta oleh konsumen. Hal ini dilakukan oleh pengrajin bambu untuk menarik konsumen tetap membeli kerajinan bambu dan penjualan kerajinan bambu tidak menurun.
Dalam memperkuat usaha kerajinan bambu skala rumah tangga terutama dalam persaingan memperoleh pelanggan tetap. Hal ini terjadi karena produk kerajinan yang ditawarkan setiap bulan mengalami kenaikan.

\section{KESIMPULAN}

1. Keuntungan yang diperoleh masing-masing usaha kerajinan bambu skala rumah tangga di Kelurahan Malumbi, Kecamatan Kambera, Kabupaten Sumba Timur Tahun 2015:

a. Keuntungan rata-rata yang diperoleh usaha kerajinan bambu kursi dan meja skala rumah tangga di Kelurahan Malumbi, Kecamatan Kambera, Kabupaten Sumba Timur rata-rata perbulan yaitu Rp. 16.218.502,00 dengan rata-rata produksi sebesar 37,08 set perbulan.

b. Keuntungan rata-rata yang diperoleh usaha kerajinan bambu gedek skala rumah tangga di Kelurahan Malumbi, Kecamatan Kambera, Kabupaten Sumba Timur rata-rata perbulan yaitu Rp. 13.066.358,00 dengan rata-rata produksi sebesar 355,41 lembar gedek perbulan.

c. Keuntungan rata-rata yang diperoleh usaha kerajinan bambu kurungan ayam skala rumah tangga di Kelurahan Malumbi, Kecamatan Kambera, Kabupaten Sumba Timur rata-rata perbulan yaitu Rp. 10,393.441,00 dengan ratarata produksi sebesar 240 buah perbulan.

2. Break even point masing-masing produk yang diperoleh dari usaha kerajinan bambu skala rumah tangga di Kelurahan Malumbi adalah :

a. Usaha kerajinan bambu kursi dan meja skalarumah tangga di Kelurahan Malumbi, Kecamatan Kambera telah mencapai 
rata-rata titik BEP volume produksi sebesar 1,00 unit dan penerimaan Rp744.406,84. Sedangkan untuk volume produksi telah mencapai titik BEP volume produksi sebesar 37,08 unit dan penerimaannya Rp 29.666.667,00.

b. Usaha kerajinan bambu gedek skala rumah tangga di Kelurahan Malumbi, Kecamatan Kambera telah mencapai rata-rata titik BEP volume produksi sebesar 8,98 unit dan penerimaan Rp. 668.860,41. Sedangkan untuk volume produksi telah mencapai titik BEP volume produksi sebesar 355,41 unit dan penerimaannya Rp. 26.656.258,00.

c. Usaha kerajinan bambu kurungan ayam skala rumah tangga di Kelurahan Malumbi, Kecamatan Kambera telah mencapai rata-rata titik BEP volume produksi sebesar 6,017 unit dan penerimaan Rp. 601.239,83. Sedangkan untuk volume produksi telah mencapai titik BEP volume produksi sebesar 239,83 dan penerimaannya Rp. 23.983.333,00.

\section{DAFTAR PUSTAKA}

Daniel, M.2002. Pengantar Ekonomi Pertanian. BumiAskara. Jakarta.

Downey, W. D and S. P. Erickson. 1992. Manajemen Agribisnis. Erlangga.

Gasperz, V.1999. Ekonomi Manajerial Pembuatan Keputusan Bisnis. PT. Gramedia. Jakarta.

Gilarso.T . 1993. Pengantar Ilmu Ekonomi Mikro. Kanisius. Yogyakarta.

Gittinger, J. Price. 1986. Analisa Ekonomi Proyek-Proyek Pertanian. Universitas Indonesia (UI-Press). Jakarta.

Kadariah, Lien Karlina dan Clive Gray. 1999. Pengantar Evaluasi Proyek. LPFEUI, Jakarta.

Nawawi, H. 1998. Metode Penelitian Bidang Sosial. Gadjah Mada University, Press. Yogyakarta.

Nazir, Moh. 2011. Metode Penelitian. Ghalia Indonesia. Jakarta.

Singarimbun, M dan Effendi, S. 1995. Metode Penelitian Survei. LP3ES. Jakarta.

Sudarman, Ari. 2002. Teori Ekonomi Mikro. UGM BPFE. Yogyakarta. 
